\title{
White Pine Blister Rust in British Columbia III. Effects on the Gene Pool of Western White Pine
}

\author{
by
}

\author{
R.S. Hunt ${ }^{1}$, E. von Rudloff ${ }^{2,3}$, M.S. Lapp ${ }^{2}$ and J.F. Manville ${ }^{1}$
}

\begin{abstract}
Cluster analyses of relative terpene abundance in foliage of western white pine (Pinus monticola Dougl.) trees from throughout the Pacific Northwest geographic range of the species were produced. Terpene patterns were randomly distributed among populations; no geographic or site trends were evident. Although blister rust is devastating to stands, the gene pool is widely distributed and may well be preserved without establishing gene banks.
\end{abstract}

About 40-50 trees selected at random would yield offspring with nearly all possible terpene patterns characteristic of the species and would thus constitute a broad genetic base. Therefore seed orchards do not necessarily need to be composed of many individuals, rather, they should contain highly selected individuals with multiple desirable traits including multiple blister rust resistance mechanisms.

Key words: terpenes, dendrogram

\section{Résumé}

L'analyse en grappes de l'abondance relative des terpènes dans le feuillage du pin argenté (Pinus monticola Dougl.) dans l'ensemble de son aire de répartition du nord-ouest du Pacifique a permis d'observer que ceux-ci étaient répartis au hasard parmi les populations et qu'il ne se dégageait aucune tendance géographique ou stationnelle. Même si la rouille vésiculeuse dévaste les peuplements, le pool génique est largement distribué et pourrait être préservé sans qu'on ait à créer de banques de gènes.

Un groupe de 40 à 50 arbres choisis au hasard pourrait donner une descendance possédant presque toutes les variations possibles de l'abondance des terpènes caractéristiques de l'essence et pourrait ainsi constituer une base génétique large. Les vergers à graines n'ont donc pas nécessairement besoin d'être constitués d'un grand nombre de sujets, mais plutôt de sujets fortement sélectionnés, aux nombreuses qualités souhaitables y compris de multiples mécanismes de résistance à la rouille vésiculeuse.

Mots clés : terpènes, dendrogramme

\section{Introduction}

Western white pine (Pinus monticola Dougl.) throughout the Pacific Northwest has suffered extensive mortality from blister rust (Cronartium ribicola J.C. Fisch. ex Rab.). In the early 1950's, in parts of the Kootenays, there were extensive young stands of western white pine. These have largely been replaced by western hemlock (Tsuga heterophylla (Raf.) Sarg.) and Douglas-fir (Pseudotsuga menziesii (Mirb.) Franco) ${ }^{3}$. Similar observations were made on the coast ${ }^{4} ; \mathrm{a}$ stand studied by Lachmund was extinct by $1949^{5}$ and on Quadra Island another is now extinct. It seems likely that both the number of stands and individuals within stands will continue to decline (Hunt 1983). Since variation in pathogenic races is known to occur (McDonald and Hoff 1975; Kinloch

\footnotetext{
1Pacific Forestry Centre, 506 West Burnside Road, Victoria, BC V8Z 1M5 2 National Research Council of Canada. Plant Biotechnology Institute, Saskatoon, SK S7N OW9

${ }^{3}$ Retired
}

and Byler 1980), the build-up of new virulent races of the pathogen may contribute to future declines.

Widespread mortality in western white pine has given rise to suggestions that the species gene pool is shrinking (Barber and Krugman 1974), and that a tree gene bank should be established from representative local populations which could be crossed with resistant selections when they become available (Hunt 1975). In contrast, the existence of considerable variation among individuals within stands, but not among stands (Hunt and von Rudloff 1977; Steinhoff et al. 1983), suggests that the gene pool is not shrinking. Furthermore, provenance trials in Idaho (Rehfeldt 1979; Steinhoff 1981; Rehfeldt et al. 1984), indicate that the species is plastic and

\footnotetext{
3Pers. comm. H. Craig former blister rust technician with W.A. Porter. ${ }^{4}$ Pers. comm. D. Collis former pest survey officer in charge of beetle survey of western white pine.
}

${ }^{5}$ File notes Pacific Forestry Centre, Victoria, BC 
that any northern-range provenance is adapted to a wide variety of sites. Thus, losses of individuals or stands of western white pine are not as important as losses in less plastic and more site-specific species. Hence the need to establish costly gene banks and to stratify breeding orchards for specific sites would be unnecessary.

Since there are these two divergent points of view, it is essential to establish the genetic variation of western white pine populations. Since terpene composition is under strong genetic control (Squillace 1976), comparative analysis of terpenes provides an approach to study genetic variation within species. Terpene patterns may also be used for indirect selection for other commercially desirable traits, particularly pest resistance (Squillace 1976). Although the relative amounts of some terpene genes are believed to be simply inherited (Hanover 1966; Squillace 1977), and therefore few indiciduals would be needed to characterize their phenotypes, others show non-modal frequency distributions indicative of control by additive genes (White and Nilsson 1984). Many individuals would therefore be needed to represent all possible terpene patterns from these latter genes. We believe the minimum number of individuals drawn at random from a group of populations that is required to express the complete variation in terpene patterns can be calculated. Too small a sample of individuals would mean that only a segment of the species variation would be represented, whereas too large a sample would contain redundant individuals.

In this study we use the approach of Lapp and von Rudloff (1980) for analysis of terpene data to study genetic variation in western white pine for possible correlations with site or geographic origins. Results of these variation studies have implications for gene conservation. The minimum number of trees drawn at random from a group of populations to maintain expression of the characteristic terpene pattern is calculated.

\section{Methods}

The majority of sample collections, their preparation, and chemical analysis have been reported previously (Hunt and von Rudloff 1977). Field collections were from various habitats from throughout the species range in the Pacific Northwest (Fig. 1). Sample trees at a site were approximately 50 to $300 \mathrm{~m}$ apart. Relative abundance of 20 terpenes were analysed in 170 trees using a computer program (Lapp 1980; Lapp and von Rudloff 1980) that computes mean-squared Euclidean distances, and clusters these distances using the unweighted centroid method to produce dendrograms indicating any genetic similarities among trees (Sneath and Sokal 1973).

Environmental and developmental factors can result in some terpene production variation within a tree. To measure this variation, foliage on branches from ground level to $6 \mathrm{~m}$ was analyzed separately for four trees. Also results from ten separate clusters of five needles were compared within eight trees, collected from a wide geographic area, by simultaneously injecting $1 \mu \mathrm{L}$ of the hexane-soluble components (obtained by grinding the individuals' needles in a mixture of hexane-water-methanol) onto two capillary gas-liquid columns (J+W Scientific Inc., DB-1 $(0.20 \mu \mathrm{m})$, i.d. $0.25 \mathrm{~mm} \times$ $20 \mathrm{~m}$; Supelcowax $10(0.25 \mu \mathrm{m})$, i.d. $0.25 \mathrm{~mm} \times 30 \mathrm{~m})$. Terpene analyses were made using a procedure equivalent to that used previously (Hunt and von Rudloff 1977).

The calculation of the minimum number of trees required to maintain the expression of the terpene pattern characteris-

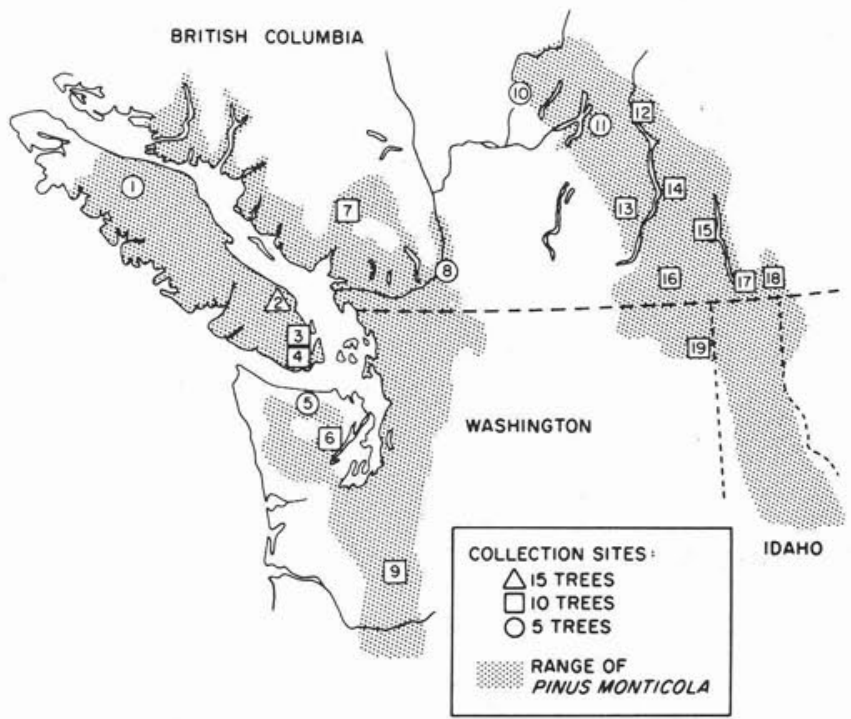

Figure 1. Collection sites of the 170 western white pine foliage samples.

tic for the populations under consideration is based on the following:

1. The populations form a homogenous assemblance, i.e., there are no geographic or site differences among western white pine populations and genes are randomly distributed among populations.

2. In defining the terpene level as a trait, the within-tree variation is an estimate for the phenotypic limits for the trait. This range of variation becomes the abscissa unit for a barhistogram of the number of individuals in a population with the same relative percentage (grouping) of a particular terpene (the abscissa reflects genetic variation within the population).

3. The sample size that will characterize the major terpene with the greatest population variation will contain more individuals than any terpene with less variation. Sufficient trees to characterize this major terpene will additionally ensure that all other terpenes will be individually characterized.

4. To calculate the minimum number of trees (MIN) it is expedient to restrict the sample to those individuals most frequently encountered. Thus we arbitrarily eliminate $10 \%$ of the uncommon individuals by removing the tail extremes of the major terpene histogram.

\section{Results}

Centroid cluster analysis (Fig. 2) indicates that there were no disjunct groups. The samples are possibly divisible into two major affinity groups, one group containing $91 \%$ of the trees and the other $9 \%$. There are no apparent geographic trends within these groups. Individual trees appear mainly randomly within the dendrogram (Fig. 2), except that a few trees from the same population are adjacent or nearly adjacent in ranking. Such apparently related groups again appear randomly within the dendrogram. 


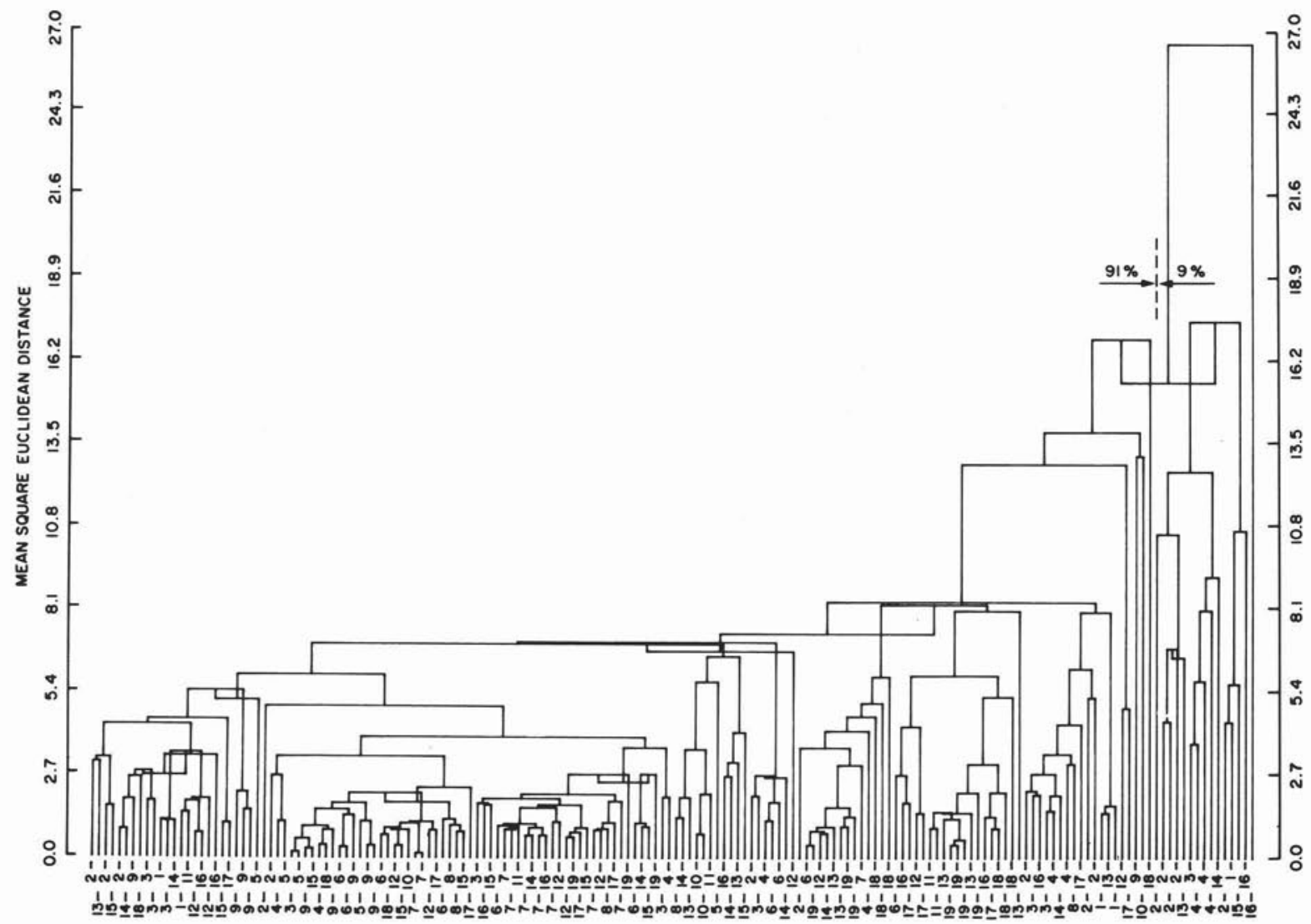

Figure 2. Dendrogram resulting from centroid cluster analysis of the mean squared Euclidean distances among the 170 western white pine trees. Numbers refer to the collection sites in Figure 1.

Variation among individual needle clusters within a tree for major terpenes was greater than variation among branches (Table 1). However, the branch to branch withintree variation for monoterpenes was seldom more than $1 \%$ (Table 1). The terpene with the largest population variation was $\beta$-pinene (Table 1; Fig. 3).

\section{Discussion}

Terpene data suggest that few western white pine individuals within a population are similar, perhaps because they are closely related. However, the terpene genes appear randomly distributed throughout the Pacific Northwest indicating that these trees form a homogenous assemblance. Therefore, although blister rust damage is dramatic, this study does not support concerns about the gene pool being reduced through extinction of specific populations or the reduction of individuals in other populations. There is no apparent need to establish a gene bank of trees susceptible to blister rust. This result is consistant with both provenance testing indicating species plasticity (Rehfeldt 1979; Steinhoff 1981; Rehfeldt et al. 1984) and resistance testing indicating a random distribution of resistant genes throughout populations (Bingham et al. 1960; Porter 1960). It would be worthwhile to determine whether a few additional geographically dispersed provenance trials,
Table 1. Minimum and maximum within-tree variation in relative percentage of major monoterpenes from foliage among western white pine trees.

\begin{tabular}{lccc}
\hline Monoterpene & \multicolumn{3}{c}{ Range of variation } \\
\hline$\alpha$-pinene & A & B & C \\
$\beta$-pinene & $1.1-7.6$ & $0.4-1.0$ & $(15.6)$ \\
Myrcene & $1.8-11.0$ & $0.6-2.8$ & $(32.8)$ \\
Car-3-ene & $0.2-0.9$ & $0.2-0.2$ & $(4.7)$ \\
Limonene & $0.0-2.0$ & $0.0-0.6$ & $(18.5)$ \\
$\alpha$-phellandrene & $0.1-1.0$ & $0.2-1.4$ & $(4.8)$ \\
$\beta$-phellandrene & $0.1-0.6$ & $0.3-0.6$ & $(4.8)$ \\
\hline
\end{tabular}

A. Variation among eight different trees with ten needle clusters sampled per tree.

B. Variation among four different trees with branch samples from four different heights.

C. Population range (max. - min.) in relative terpene percentage.

and data for characters other than terpene composition, would support this conclusion.

The within-tree variation is reduced by increasing the size of each sample (Table 1). The terpene with the largest population variation, $\beta$-pinene, had a maximum branch to branch, within-tree variation of $2.8 \%$ (Table 1 ); however, we conserva- 


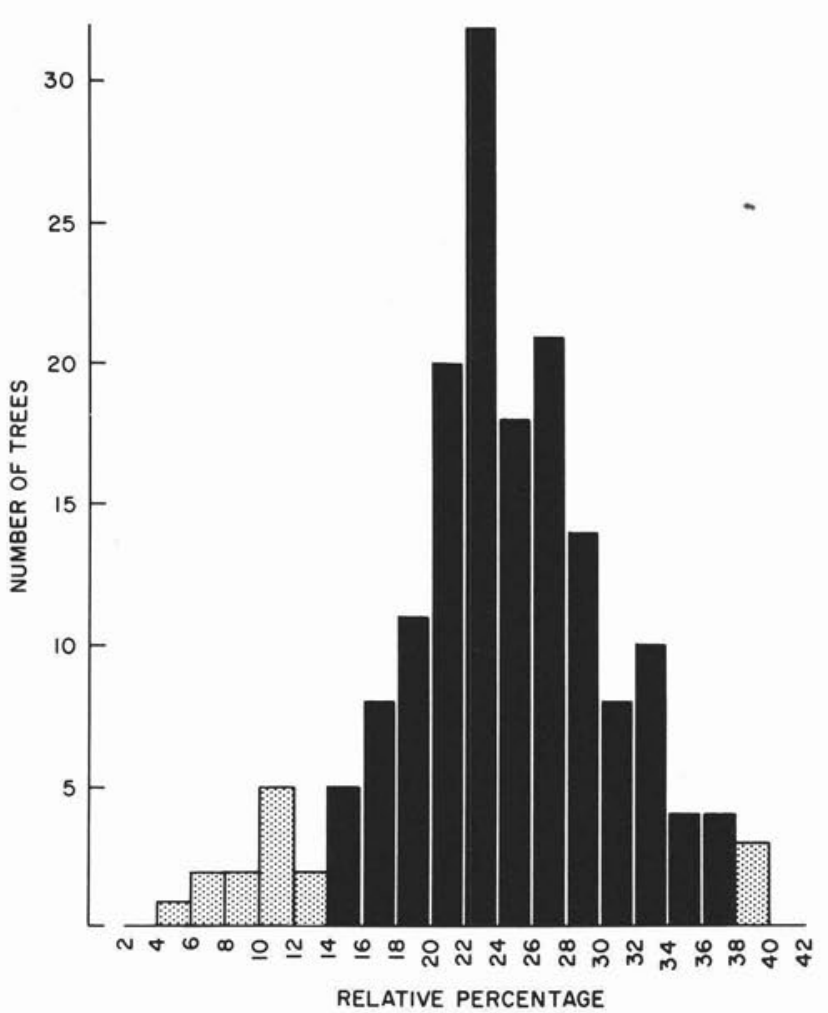

Figure 3. Frequency distribution for $\beta$-pinene in the leaf-oil of 170 western white pine trees. Extreme individuals, at the tails of the distribution, are stippled and they represent less than $10 \%$ of the population.

tively chose a minimum needle variation value of $2 \%(1.8 \%)$ in constructing Figure 3. By eliminating the tail extremes of this figure $(10 \%$ of the original 170 trees) we reduce the population to 153 trees, four of which have $\beta$-pinene percentages at either end of the distribution. This ratio (153:4) reduces to one tree in 38 , i.e., a sample size of 38 individuals drawn at random will yield a population containing $90 \%$ of the variation in terpene characteristics, or the MIN value. We do not expect that refinements in defining the variation of a particular phenotype will markedly affect the number of extreme individuals in a population and thus the MIN value. For instance, if we had chosen an abscissa unit of $1 \%$ for construction of Figure 3 , the MIN value would have increased to only 51 trees.

When selecting for pest resistance, it is desirable to obtain a large gene base to buffer or minimize losses to al causes. However, each screening for blister rust resistance takes about seven years and developing a large gene base for seed orchards will take many screenings. Thus the procedure is long and expensive (Bingham 1983). It is therefore desirable to limit the size of the seed orchard. The data presented here suggest that the variation in terpene patterns can be ignored when selecting desirable western white pines if 40-50 unrelated individuals are randomly selected, because they would yield a total terpene variation likely greater than $90 \%$ of that found in the Pacific Northwest. Likewise, the total number of resistance mechanisms known in the species for blister rust control (Hoff and McDonald 1980) could readily be found in 40 individuals. Whether this would limit variation in other characteristics is not known. To safeguard against this possibility we support the concept of ecological reserves wherein the natu- ral gene pools are maintained. In addition, this could also be augmented with a seed bank

Compared with agricultural multilines which contain considerably less genetic variation but are generally considered stable against various pests (Breth 1976; Wolfe and Barrett 1980), a MIN seed orchard would contain considerable genetic resources. The genotype output of a MIN seed orchard will be even more varied than the genotypes of the parents because many of the parents will be heterozygous. If outbreeding occurs randomly, not only are all possible combinations for a particular terpene likely to occur, but all possible combinations among all terpenes should be possible.

Current western white pine blister rust programs contain hundreds of selections (Theisen 1974; Bingham 1983). However, data presented here suggest that a program should concentrate on critically screening resistant candidates to find fewer elite individuals with multiple resistant mechanisms and other desirable traits at the expense of having a greater number of individuals of lesser quality.

\section{References}

Barber, J.C. and S.L. Krugman. 1974. Preserving forest-tree germ plasm. Am. For. 80: 8-11, 42-43.

Bingham, R.T. 1983. Blister rust resistant western white pine for the Inland Empire. USDA. For. Serv. Gen. Tech. Rept. INT-146.

Bingham, R.T., A.E. Squillace, and J.W. Wright. 1960. Breeding blister rust resistant western white pine. II. First results of progeny tests including preliminary estimates of heritability and rate of improvement. Silvae Genet. 9: 33-41

Breth, S.A. 1976. Multilines - safety in numbers. CIMMYT today, no. 4, p. 1-9.

Hanover, J.W. 1966. Inheritance of 3-carene concentration in Pinus monticola. For. Sci. 12: 447-450.

Hoff, R.J. and G.I. McDonald. 1980. Improving rust-resistant strains of inland western white pine. USDA. For. Serv. Res. Pap. INT -245 .

Hunt, R.S. 1975. An examination of the research options for white pine blister rust in British Columbia. Can. For. Serv., Pac. For. Res. Centre. File Rept. PC-13-114, 26 p.

Hunt, R.S. 1983. White pine blister rust in British Columbia II. Hazard rating stands. For. Chron. 59: 30-33

Hunt, R.S. and E. von Rudloff. 1977. Leaf-oil-terpene variation in western white pine populations of the Pacific Northwest. For. Sci. 23: 507-516

Kinloch, B.B. and J.W. Byler. 1980. Relative effectiveness and stability of different resistance mechanisms to white pine blister rust in sugar pine. Phytopathology 71: 386-391

Lapp, M.S. 1980. A numerical taxonomy system for small computers. National Research Council of Canada, Saskatoon, SK.

Lapp, M.S. and E. von Rudloff. 1980. The use of mini- and microcomputers in numerical taxonomy. Botany 80 . Vancouver, B.C. July 12-16. Bot. Soc. Am. Misc. Ser. 158.

McDonald, G.I., and R.J. Hoff. 1975. Resistance to Cronartium ribicola in Pinus monticola: an analysis of needle-spot types and frequencies. Can. J. Bot. 53: 2497-2505

Porter, W.A. 1960. Testing for resistance to the blister rust disease of western white pine in British Columbia. Can. Dep. Ag. Forest Biol. Div., Victoria, B.C. p. 1-19, 8 fig.

Rehfeldt, G.E. 1979. Ecotypic differentiation in populations of Pinus monticola in north Idaho - myth or reality? Am. Nat. 114: 627-636.

Rehfeldt, G.E., R.J. Hoff and R.J. Steinhoff. 1984. Geographic patterns of genetic variation in Pinus monticola. Bot. Gaz. 145: 229-239.

Sneath, P.H.A. and R.R. Sokal. 1973. Numerical Taxonomy. The Principles and Practise of Numerical Classification. W.H. Freeman and Co., San Francisco. $573 p$.

Squillace, A.E. 1976. Analysis of monoterpenes of conifers by gasliquid chromatography. In: J.P. Miksche (ed.), Modern Methods in Forestry Genetics. Springer-Verlag. New York. p. 120-157. 
Squillance, A.E. 1977. Use of monoterpene composition in forest genetics research with slash pine. Proc. South. For. Tree Improv. Conf. 14: 227-238.

Steinhoff, R.J. 1981. Survival and height growth of coastal and interior western white pine saplings in north Idaho. USDA For. Serv. Res. Note INT 303.

Steinhoff, R.J., D.G. Joyce and L. Fins. 1983. Isozyme variation in Pinus monticola. Can. J. For. Res. 13:1122-1132.
Theisen, P.A. 1974. U.S. Forest Service Region 6. Industrial Forestry Association Tree Improvement Newsletter 21: 5-6.

White, E.E. and J.E. Nilsson. 1984. Foliar terpene heritability in Pinus contorta. Silvae Genet. 33: 16-22.

Wolfe, M.S. and J.A. Barrett. 1980. Can we lead the pathogen astray? PI. Dis. 64: 148-155

\section{IMPROVED TECHNOLOGY IN DISC TRENCHERS}

The MM DISC TRENCHERS from Finland: The most effective in Finland for 20 years, they will do the job better for you in Canada.

Contact us for details:

CANADIAN FORESTRY EQUIPMENT LTD.

$\begin{array}{lcc}\text { Edmonton, Alta } & \text { Mississauga, Ont. } & \text { Dartmouth, N.S. } \\ \text { (403)-484-6687 } & (416)-678-1586 & (902)-465-2558\end{array}$
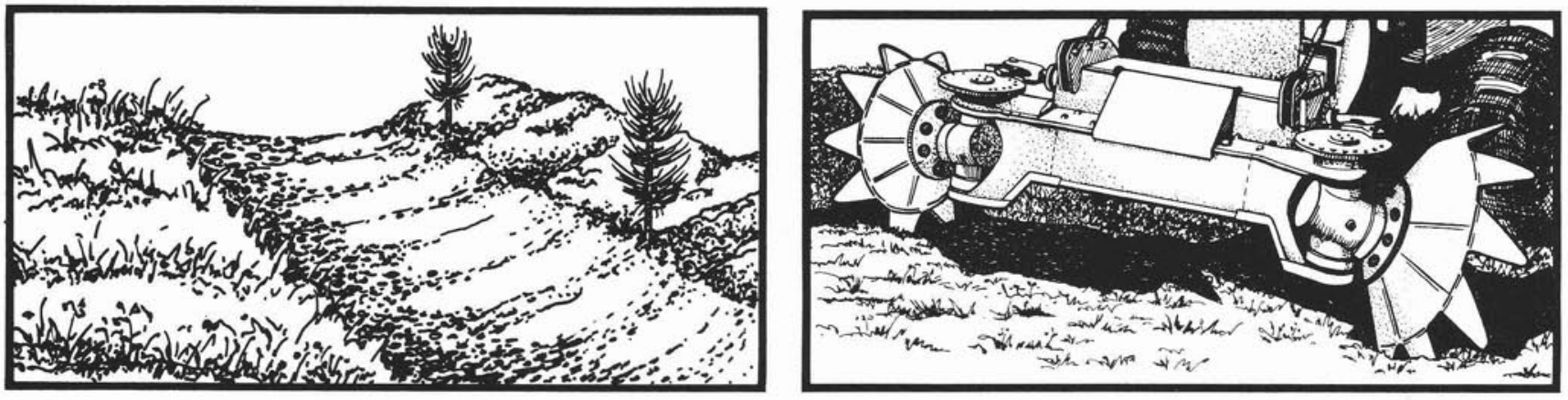